\title{
WEZWANIE DO USUNIĘCIA NARUSZENIA PRAWA - ZBĘDNY ELEMENT W PRZEPISACH PROCEDURY SĄDOWOADMINISTRACYJNEJ?
}

\section{WSTĘP}

Celem niniejszego opracowania jest zwrócenie uwagi na wyeliminowanie z postępowania sądowoadministracyjnego w połowie roku 2017 wezwania do usunięcia naruszenia prawa. Ten środek prawny obligatoryjnie poprzedzał składanie skarg do sądu administracyjnego I instancji na akty i czynności, o których mowa w art. 3 § 2 pkt 4 i 4a ustawy z 30 sierpnia 2002 r. o postępowaniu przed sąami administracyjnymi ${ }^{1}$, oraz inne akty, wydawane w sprawach, w których przepisy ustaw szczególnych przewidują sądową kontrolę administracji publicznej. Jego zakres zastosowania był bardzo szeroki. Wezwanie do usunięcia naruszenia prawa należało złożyć przed wniesieniem skargi na akty prawa miejscowego, na akty lub czynności z zakresu administracji publicznej inne niż decyzja czy postanowienie, dotyczące uprawnień lub obowiązków wynikających z przepisów prawa, na pisemne interpretacje przepisów prawa podatkowego wydawane w sprawach indywidualnych, a także na bezczynność w tych sprawach. Na mocy art. 102a ustawy z 8 marca 1990 r. o samorządzie gminnym, wprowadzonego do tej ustawy przez art. 1 pkt 66 ustawy z 11 kwietnia 2001 r. $^{2}$ zmieniającej nin. ustawę, z dniem 30 maja 2001 r. wymóg wezwania do usunięcia naruszenia prawa przed wniesieniem skargi do sądu administracyjnego został zniesiony w odniesieniu do uchwał i zarządzeń organów gmin podejmowanych w sprawach z zakresu administracji publicznej. Analogiczne wyłączenia wprowadzone zostały w późniejszym czasie w odniesieniu do uchwał organów powiatu oraz organów samorządów województw. Uwzględnienia wymaga także treść art. 17 ust. 2 ustawy z 7 kwietnia 2017 r. o zmianie ustawy Kpa oraz o zmianie niektórych innych ustaw $^{3}$, zgodnie z którym zwolnienie $\mathrm{z}$ wymogu wezwania do usunięcia naruszania prawa $\mathrm{w}$ stosunku do uchwał organów powiatów oraz organów samorządów województw dotyczy jedynie aktów podjętych po dniu 1 czerwca 2017 r., a więc uchwał podjętych po wejściu w życie ustawy z 7 kwietnia 2017 r. Przykładem aktów i czynności, o których mowa w art. $3 \S 2$ pkt 4 p.p.s.a., są (liczne i zróżnicowane) czynności materialno-techniczne, akty rejestracji lub wykreślenia z rejestru, odmo-

\footnotetext{
${ }^{1}$ Tjedn.: Dz. U. 2018, poz. 1302 ze zm. (dalej jako: p.p.s.a.).

2 Dz.U. 2001, Nr 45, poz. 497.

${ }^{3}$ Dz. U. 2017, poz. 935.
} 
wa uznania lub stwierdzenia przez właściwy organ administracji publicznej uprawnień wynikających bezpośrednio z przepisów prawa ${ }^{4}$. Jeżeli ustawa nie przewidywała środków zaskarżenia w sprawie będącej przedmiotem skargi, np. w przypadku decyzji ostatecznych z mocy ustaw szczególnych, albo uchwał będaccych aktami prawa miejscowego, uprawniony podmiot przed wniesieniem skargi do sądu także obowiązany był zwrócić się wcześniej do właściwego organu z uprzednim wezwaniem do usunięcia naruszenia prawa ${ }^{5}$.

Autorka niniejszego opracowania podjęła się próby udzielenia odpowiedzi na pytanie, w jakiej mierze zabieg wyeliminowania wezwania do usunięcia naruszenia prawa (z przepisów ustawy p.p.s.a.), warunkujący dotychczas skuteczność wniesienia skargi do sądu administracyjnego, był uzasadniony i czy zerwanie z utrwalonym sposobem prowadzacym do kwestionowania różnych form aktywności administracji publicznej oraz jej braku można ocenić pozytywnie. Przy tej okazji autorka wskazuje, że mimo wykluczenia tego środka prawnego z przepisów p.p.s.a. nadal funkcjonuje on w polskim prawodawstwie.

\section{UWARUNKOWANIA SĄDOWEJ KONTROLI ADMINISTRACJI}

W niektórych systemach prawnych zwrócenie się o ochronę do sądu administracyjnego nie wymaga uruchomienia żadnych środków kontroli przedsądowej. Takie rozwiązania występuja w krajach, w których prawodawca dopuszcza dokonywanie wyboru prawnej drogi kwestionowania poczynań administracji ${ }^{6}$.

Odmiennie kwestia ta jest uregulowana w niemieckim systemie prawnym, gdzie wyczerpanie określonej procedury wstępnej - podobnie jak w wielu innych krajach - traktowane jest jako warunek uruchomienia kontroli sądowej aktów administracyjnych ${ }^{7}$. W Niemczech administracyjne postępowanie odwoławcze jest sprzężone z procesem sądowym i ma charakter przedsądowego postępowania wstępnego (Vorverfahren). Jego celem jest dokonanie kontroli przez organ administracji publicznej z punktu widzenia legalności i celowości aktu przed wniesieniem skargi do sądu administracyjnego. W niemieckiej nauce prawa rozwiązanie to ocenia się pozytywnie. Sprzyja ono odciążeniu sądów administracyjnych i zapobiega niepotrzebnemu angażowaniu sądu w spór mogący znaleźć swoje rozwiązanie przed organem. Dzięki niemu część sporów udaje się rozstrzygnać w trybie przedsądowym. Administracji zapewnia to możliwość weryfikacji aktów we własnym zakresie, ponieważ sprzeciw (Wiederspruch), uruchamiajacy postępowanie wstępne, w pierwszej kolejności rozpoznawany jest w ramach autokontroli przez organ, który wydał zaskarżo-

${ }^{4}$ Zob. szerzej Szewczyk (2011): 639-641; zob. również Łaszczyca, Martysz, Matan (2005): 367 n; Kisielewicz (2009): $167 \mathrm{n}$.

${ }^{5}$ Wiktorowska (2007): 411.

${ }^{6}$ Zob. szerzej na temat rozwiązań obowiązujących w tym zakresie Kmieciak (2010): $27 \mathrm{n}$.

${ }^{7}$ Kmieciak (2009): 142-143. 
ny akt. Obywatel natomiast ma dzięki temu dodatkową i tanią formę kontroli administracji publicznej dokonywanej przez nią sama. W niemieckim systemie prawnym wyczerpanie postępowania wstępnego stanowi, co do zasady, warunek dopuszczalności skargi do sądu administracyjnego ${ }^{8}$.

Rozwiązanie prawne, w którym występuje konstrukcja postępowania przedsądowego czy wstępnego, w prawie europejskim określana jest mianem administrative preliminary proceedings. W nauce postępowania sądowoadministracyjnego oprócz jej licznych zalet, do których należy przede wszystkich odciążenie sądownictwa, z czasem zaczęto dostrzegać pewien jej aspekt negatywny: jeżeli bowiem postępowanie wstępne nie odniesie pozytywnego rezultatu, opóźnia ono jedynie uzyskanie dostępu do sądu. Z tego względu ustawodawstwo niektórych państw dopuszcza, przynajmniej gdy chodzi o pewne rodzaje sporów, wybór prawnej drogi kwestionowania aktów (działań) organów administracji publicznej ${ }^{9}$.

Uogólniając, można powiedzieć, że dość powszechne jest podejście, w myśl którego spór sądowy traktowany jest jako swego rodzaju ostateczność. Opierając się na tym założeniu, prawodawca dba o stworzenie odpowiednich mechanizmów selekcji wnoszonych skarg i środków skłaniających do większej powściagliwości w korzystaniu z sądowej drogi dochodzenia swoich racji, aby droga ta nie była uruchamiana w sposób nieprzemyślany ${ }^{10}$.

\section{POLSKA KONCEPCJA SĄDOWEJ KONTROLI ADMINISTRACJI}

W tradycji polskiego systemu prawnego sądowa kontrola administracji z założenia nie stanowiła pierwszego ani zasadniczego ogniwa tego systemu. Traktowano ja jako ostateczny czynnik weryfikacji działań organów administracji publicznej, wchodzący w grę dopiero wówczas, gdy inne mechanizmy, w ocenie skarżącego, zawiodły. $Z$ tego powodu konstrukcja art. 52 p.p.s.a. zakładała, że wniesienie skargi do sądu administracyjnego może nastapić, gdy wyczerpano wszelkie sposoby załatwienia sprawy na forum administracji ${ }^{11}$. Polski model sądowej kontroli administracji opiera się bowiem na założeniu, że zainicjowanie postępowania sądowoadministracyjnego powinno zostać poprzedzone wyczerpaniem wszelkich procesowych możliwości osiagnięcia zamierzonego celu postępowania jeszcze przed organem administracji publicznej ${ }^{12}$. Jego realizacja sprzyja odciążeniu sądów od rozpoznawania spraw, które moga znaleźć swój finał przed organami administracji. Jednostkom zaś zapewnia brak nadmiernego uwikłania w spory sądowe ${ }^{13}$.

\footnotetext{
8 Zob. szerzej Schmidt (2011): 365-366; Glaezer (1992): 109.

9 Kmieciak (2015): 135.

${ }^{10}$ Chróścielewski, Kmieciak, Tarno (2004): 64.

11 Chróścielewski (2003): 25.

12 Piątek (2017): 427.

13 Piątek (2017): 427.
} 
W dotychczasowych rozwiązaniach prawnych ustawodawca uwarunkował prawo do wniesienia skargi uprzednim wyczerpaniem przez skarżacego przysługujących mu na drodze administracyjnoprawnej środków zaskarżenia ${ }^{14}$. Jeśli ustawa nie przewidywała środków zaskarżenia, wniesienie skargi do sądu musiało zostać poprzedzone uprzednim wezwaniem właściwego organu administracji publicznej do usunięcia naruszenia prawa. Jego celem było umożliwienie organowi załatwienia sprawy bez konieczności wnoszenia skargi do sądu administracyjnego ${ }^{15}$.

Wezwanie do usunięcia naruszenia prawa, jako konstrukcja skorelowana $\mathrm{z}$ trybem wniesienia skargi do sądu administracyjnego, pojawiło się $\mathrm{w}$ przepisach ustawy o samorządzie terytorialnym z $1990 \mathrm{rr}^{16} \mathrm{i}$ z czasem zyskało utrwalona pozycję w systemie środków prawnych ${ }^{17}$. Jego konstrukcja spełniała wymóg sformułowany w pkt B.2.b. Rekomendacji Komitetu Ministrów Rady Europy Rec. (2004)20 z 15 grudnia 2004 r. o sądowej kontroli aktów administracyjnych (on Judicial Review of Administrative Acts). Jak wynika z jej uregulowań, zaskarżenie przez osobę fizyczną lub prawną aktu organu administracji do sądu może być uzależnione od wcześniejszego uruchomienia przewidzianych przez prawo krajowe środków ochrony ${ }^{18}$. W polskim porządku prawnym zaliczano do nich wezwanie do usunięcia naruszenia prawa ${ }^{19}$. Aby środek ten nie opóźniał (w razie jego bezskuteczności) dostępu do sądu, Rekomendacja wskazuje, że postępowanie wstępne nie powinno być zbyt długie. Skarżącemu bowiem należy zapewnić rozsądny okres (a reasonable period of time) do wniesienia skargi. W literaturze przedmiotu wskazuje się, że rozwiązanie takie przynosi wiele korzyści. Sprzyja ono odciążeniu sądów, co przekłada się na zapewnienie im sprawnego funkcjonowania i leży zarówno w interesie wymiaru sprawiedliwości, jak i samej administracji ${ }^{20}$.

Jak już wskazano, do niedawna w polskim systemie prawnym wcześniejsze skierowanie do organu administracji publicznej wezwania do usunięcia naruszenia prawa było warunkiem sine qua non skuteczności skargi. Niespełnienie tej przesłanki prowadziło bezwzględnie do odrzucenia skargi przez sąd administracyjny jako przedwczesnej ${ }^{21}$. Postępowanie sądowoadministracyjne nie mogło być bowiem uruchomione, jeżeli nie zostały wykorzystane środki weryfikacji kwestionowanych aktów, czynności i bezczynności dostępne podmiotowi, który zamierzał je poddać ocenie sądu administracyjnego ${ }^{22}$. Obecnie jednak z tego rozwiązania ustawodawca zrezygnował.

14 Fundowicz (2003): 138 n.

15 Uchwała składu 7 sędziów NSA z 2 kwietnia 2007 r., II OPS 2/07, ONSAiWSA 2007, nr 3, poz. 60.

16 Przepis art. 101 ust. 1 ustawy o samorządzie terytorialnym, Dz. U. Nr 16, poz. 95.

17 Kmieciak (2013): $25 \mathrm{n}$.

18 Chlebny (2010): 37.

19 Kmieciak (2010): 115.

${ }^{20}$ Kmieciak (2015): 134.

21 Piątek (2013): 30 n.

22 Tarno (2016): 444. 


\section{POZYTYWNE ASPEKTY WEZWANIA DO USUNIĘCIA NARUSZENIA PRAWA}

Do zalet wezwania do usunięcia naruszenia prawa należało między innymi to, że sporządzenie wezwania w formie pisemnej miało powstrzymywać skarżącego przed nierozważnym uruchamianiem drogi sądowej. Wezwanie do usunięcia naruszenia prawa pozwalało nawiązać komunikacje między jednostka a administracja. Wymogiem formalnym bowiem było zachowanie formy pisemnej bądź formy dokumentu elektronicznego. Celem tego środka prawnego było skłonienie organu do rozważenia potrzeby zweryfikowania własnego zachowania i dokonania jego autorewizji w obliczu groźby wniesienia skargi do sądu administracyjnego. Stanowiło ono wyraz niezadowolenia uprawnionego podmiotu z powodu treści danego aktu lub czynności albo ich braku. Było ono jednocześnie zapowiedzią ich zaskarżenia do sądu administracyjnego. Z kolei po jego wniesieniu wnoszacy wezwanie miał czas na przemyślenie swoich kolejnych kroków prowadzących do zaskarżenia aktu lub czynności organu administracji publicznej, w tym - o ile odpowiedź na wezwanie została udzielona - przemyślenia racji w niej przedstawionych ${ }^{23}$. Samo wezwanie zaś i odpowiedź na nie (o ile została udzielona) dostarczały dodatkowego materiału pomocnego w postępowaniu przed sądami administracyjnymi ${ }^{24}$.

\section{KONTROWERSJE ZWIĄZANE Z WEZWANIEM DO USUNIĘCIA NARUSZENIA PRAWA}

Charakter prawny wezwania do usunięcia naruszenia prawa w doktrynie prawa i postępowania administracyjnego oraz w orzecznictwie sądów administracyjnych należał do kwestii spornych. Niekiedy kwalifikowano je jako nadzwyczajny środek zaskarżenia, nadzwyczajny środek prawny, surogat środka zaskarżenia bądź surogat środka odwoławczego. Określano je też mianem „środka obrony”, a także „specjalnym środkiem prawnym”. Kontrowersje wzbudzało także to, na podstawie jakich przepisów dochodziło do wydania nowej decyzji w trybie autoweryfikacji po wniesieniu skargi sadowoadministracyjnej. W dorobku judykatury prezentowano stanowisko, że wezwanie przewidziane $^{25} \mathrm{w}$ art. $52 \S 3$ i $\S 4$ p.p.s.a. nie jest instytucją postępowania administracyjnego ${ }^{26}$, choć obecne były też w doktrynie poglądy przeciwne ${ }^{27}$.

${ }^{23}$ Kmieciak (2017): 57.

${ }^{24}$ Kmieciak (2015): 143.

25 Zob. szerzej Szewczyk (2018): 138-141 i powołana tam literatura przedmiotu oraz orzecznictwo.

${ }^{26}$ Wyrok WSA w Lublinie z 15 lutego 2017 r., I SA/Lu 33/16.

27 Zob. szerzej Szewczyk (2018): 138-141 i powołana tam literatura przedmiotu. 


\section{WYKLUCZENIE WEZWANIA DO USUNIĘCIA NARUSZENIA PRAWA Z PRZEPISÓW P.P.S.A.}

Jak już nadmieniono, reformując postępowanie sądowoadministracyjne, ustawodawca wyeliminował instytucję wezwania do usunięcia naruszenia prawa z polskiego porządku prawnego ${ }^{28}$. W odniesieniu do postępowań sądowoadministracyjnych wszczynanych od 1 czerwca $2017 \mathrm{r}$. stosuje się przepisy p.p.s.a. w brzmieniu obowiązującym od tej daty. Na mocy przepisów ustawy z 7 kwietnia 2017 r. $^{29}$ reformujących postępowanie administracyjne oraz postępowanie sądowoadministracyjne ustawodawca zmienił brzmienie $\S 3 \mathrm{w}$ art. 52 p.p.s.a., nadając mu inną treść, oraz uchylił $\S 4 \mathrm{w}$ art. 52 p.p.s.a. W ten sposób wspomniana nowelizacja zlikwidowała obowiązek kierowania do organu administracji publicznej wezwania do usunięcia naruszenia prawa, który dotychczas był etapem warunkującym możliwość wniesienia skargi do sądu administracyjnego I instancji ${ }^{30}$. Powyższe nie dotyczy postępowań sądowoadministracyjnych wszczynanych także po tej dacie, a dotyczących uchwał organów powiatów i samorządów województw, o których mowa w art. 17 ust. 2 ustawy z 7 kwietnia 2017 r. ${ }^{31}$, która weszła w życie z dniem 1 czerwca 2017 r.

Obecnie, gdy ustawa nie przewiduje środków zaskarżenia w sprawie będącej przedmiotem skargi, uprawniony podmiot, bez konieczności uprzedniego wzywania organu do usunięcia naruszenia prawa, może złożyć skargę do sądu administracyjnego - w terminie 30 dni od dnia, w którym dowiedział się o wydaniu aktu lub podjęciu innej czynności. W przypadku indywidualnych interpretacji podatkowych (art. $3 \S 2$ pkt 4a p.p.s.a.) termin na wniesienie skargi wynosi 30 dni od dnia doręczenia interpretacji skarżącemu. W przypadku innych aktów skargę można wnieść w każdym czasie. Dotyczy to takich aktów lub czynności, w stosunku do których ustawa nie przewiduje środków zaskarżenia ani nie stanowi inaczej (art. $52 \S 4$ p.p.s.a.). W wyniku nowelizacji wprowadzono również konieczne zmiany w przepisach ustaw samorządowych (o samorządzie gminnym, powiatowym i województwa) oraz w ustawie o wojewodzie i administracji rządowej w województwie, w których dotychczas przed wniesieniem skargi na uchwałę lub zarządzenie organu jednostki samorządu terytorialnego, a także akty prawa miejscowego wojewodów również przewidywano konieczność uprzedniego wezwania organu do usunięcia naruszenia prawa.

28 Adamiak (2017): 530.

${ }_{29}$ Ustawa o zmianie ustawy - Kodeks postępowania administracyjnego oraz niektórych innych ustaw, Dz. U. 2017, poz. 935.

${ }^{30}$ Wyrok WSA w Krakowie z 22 listopada 2018 r., III SA/Kr 867/18.

31 Dz. U. 2017, poz. 935. 


\section{WEZWANIE DO USUNIĘCIA NARUSZENIA PRAWA POZA PRZEPISAMI P.P.S.A.}

Wyeliminowanie wezwania do usunięcia naruszenia prawa z przepisów p.p.s.a. nie oznacza jednak, że ten środek prawny w naszym prawodawstwie nie występuje. Wymóg wniesienia wezwania do usunięcia naruszenia prawa mógł też wynikać z rozwiązań przyjętych w odrębnych ustawach. Polski ustawodawca przed wieloma laty wprowadził go do przepisów tzw. ustawy rewindykacyjnej, która miała rozwiązać problem mienia związków zawodowych utraconego w wyniku wprowadzenia stanu wojennego 13 grudnia $1980 \mathrm{r}$. Ustawa ta w orzecznictwie sądów administracyjnych była traktowana jako akt szczególny. Przekazała ona bowiem na drogę postępowania administracyjnego sprawy, które ze swej istoty są sprawami cywilnymi (roszczenia majątkowe) ${ }^{32}$. Środek prawny, jakim jest wezwanie do usunięcia naruszenia prawa, został przewidziany w art. 7 ust. 3 ustawy z 25 października 1990 r. - O zwrocie majątku utraconego przez związki zawodowe i organizacje społeczne w wyniku wprowadzenia stanu wojennego ${ }^{33}$. W unormowanym tym przepisem szczególnym przypadku warunkiem wniesienia skargi do sądu administracyjnego nie było uprzednie wniesienie wniosku o ponowne rozpatrzenie sprawy od orzeczenia Społecznej Komisji Rewindykacyjnej o zwrocie majątku odebranego związkom zawodowym i organizacjom społecznym, na skutek wprowadzenia stanu wojennego, lecz skierowania do tejże Komisji wezwania do usunięcia naruszenia prawa $\mathrm{w}$ terminie 21 dni od dnia doręczenia orzeczenia w przedmiocie zwrotu ${ }^{34}$. W myśl art. 7 ust. 3 z.m.u.z.z.o.s. z wezwaniem należy zwrócić się w terminie 21 dni od dnia doręczenia orzeczenia Społecznej Komisji Rewindykacyjnej. W terminie 30 dni od dnia wpływu wezwania Komisja może je uwzględnić w drodze uchylenia lub zmiany dotychczasowego orzeczenia (art. 7 ust. 4 z.m.u.z.z.o.s.). Nowe orzeczenie wydane w trybie uwzględnienia wezwania do usunięcia naruszenia prawa podlega zaskarżeniu do sądu administracyjnego z pominięciem trybu wezwania (art. 7 ust. 4 z.m.u.z.z.o.s.).

Podkreślenia wymaga, że mimo iż w przepisach p.p.s.a. ustawodawca zrezygnował z instytucji wezwania do usunięcia naruszenia prawa, pozostawił je w art. 7 ust. 3 z.m.u.z.z.o.s. W ten sposób przewidziany w z.m.u.z.z.o.s. środek prawny w postaci wezwania do usunięcia naruszenia prawa zaczą niejako żyć własnym życiem, niezależnie od braku takiego środka (od dnia 1 czerwca 2017 r.) w przepisach normujacych postępowanie sądowoadministracyjne. Prowadzi to do konkluzji, że w polskim systemie prawnym nadal istnieje samoistny środek prawny w postaci wezwania do usunięcia naruszenia prawa. Jest to samodzielny środek prawny - będacy przykładem remonstracji w czystej postaci - którego wniesienie nie jest uzależnione od wniesienia innego

\footnotetext{
32 Wyrok WSA w Warszawie z 20 lutego 2002 r., II SA 3139/00.

${ }^{33}$ T.jedn.: Dz. U. 1996, Nr 143, poz. 661 ze zm. (dalej jako: z.m.u.z.z.o.s.).

34 Uchwała SN z 5 listopada 1997 r., III ZP 34/97, OSNP 1998, nr 4, poz. 105.
} 
środka prawnego. Nie jest on również „wmontowany” w inny środek prawny - tak jak w przypadku remonstracji „ukrytej” w skardze do wojewódzkiego sądu administracyjnego ${ }^{35}$. Jest on jednak uregulowany poza przepisami normującymi postępowanie sądowoadministracyjne i dotyczy incydentalnych przypadków normowanych wskazaną wyżej ustawą z.m.u.z.z.o.s. Jej przepisy były podstawą licznych postępowań w latach dziewięćdziesiątych oraz wkrótce po roku 2000. Mimo że nadal one obowiązuja, przyznać trzeba, że ich praktyczne znaczenie zmalało, gdyż - jak można przypuszczać - większość spraw, do których miały zastosowanie przepisy tej ustawy, już została przeprowadzona.

\section{CHARAKTER PRAWNY WEZWANIA DO USUNIĘCIA NARUSZENIA PRAWA}

Wezwanie do usunięcia naruszenia prawa uregulowane $\mathrm{w}$ przepisach p.p.s.a. to przykład remonstracji w jej czystej postaci ${ }^{36}$. Stanowiło ono prośbę kierowana przez jednostkę do tego samego organu administracji publicznej, którego działanie kwestionowano, organ ten zaś nie miał obowiązku nawet na nią odpowiedzieć. Wezwanie do usunięcia naruszenia prawa było więc niedoskonałym środkiem prawnym (owa niedoskonałość jest opisem rzeczywistej cechy tego środka, a nie jego negatywną charakterystyka), którego wniesienie nie dawało jednostce roszczenia procesowego. W przypadku remonstracji uprawnienia skoncentrowane sa bowiem po stronie podmiotu, do którego jest ona kierowana i który ma swobodę w decydowaniu o stopniu zaangażowania się w sprawęę7.

Współcześnie remonstracja stała się trwałym elementem autokontroli działań administracji publicznej ${ }^{38}$. Występuje ona w licznych odmianach - uzupełniając system środków prawnych doskonałych. Może występować w jednej z dwóch postaci. Samoistnej, gdy jest to środek prawny całkowicie niezależny od jednoczesnego wniesienia innego środka prawnego. A także niesamoistnej - niesamodzielnej, gdyż towarzyszy ona innym środkom prawnym i jej istnienie zależy od wniesienia takiego środka.

\section{MOTYWY WYELIMINOWANIA WEZWANIA DO USUNIĘCIA NARUSZENIA PRAWA}

Trudno wskazać, jakie motywy przemawiały za wyeliminowaniem z polskiego porządku prawnego instytucji wezwania do usunięcia naruszenia prawa. Nie wskazano ich w opracowaniu dostępnym na stronie internetowej Mi-

\footnotetext{
35 Zob. szerzej Szewczyk (2018): 119.

36 Szewczyk (2017): 575.

37 Zob. szerzej Szewczyk (2018): 33, 57, 68.

38 Kmieciak (2013): 31.
} 
nisterstwa Przedsiębiorczości i Technologii: „Nowelizacja KPA - czego dotycza zmiany i jak je stosować"39. Natomiast z wyjaśnienia zawartego w uzasadnieniu projektu nowelizacji dostępnym na stronie rządowego portalu konsultacji społecznych wynika, że przemawiać miał za tym rozwiązaniem fakt bardzo rzadkiego reagowania na owe wezwania ze strony organów administracji publicznej, przez co można było odnieść wrażenie, że jest to środek wyjątkowo mało efektywny ${ }^{40}$.

Usunięcie z polskiego porządku prawnego wezwania do usunięcia naruszenia prawa Zbigniew Kmieciak słusznie ocenił jako zabieg niefortunny i nieprzemyślany ${ }^{41}$. Podkreślenia wymaga, że wyeliminowanie wezwania do usunięcia naruszenia prawa nie oznacza, że w sprawach, których przedmiotem skargi sa akty i czynności, o których mowa w art. $3 \S 2$ pkt 4 i 4 a oraz inne akty (czyli w sprawach, w których dotychczas skarżący obowiązany był wnieść wezwanie do usunięcia naruszenia prawa, pozwalające organowi administracji publicznej na zastosowanie trybu remonstracji), ustawodawca nie zapewnił możliwości zweryfikowania własnego działania na skutek wniesienia skargi. Zgodnie bowiem z art. $54 \S 1$ p.p.s.a. skargę wnosi się w trybie pośrednim, a więc za pośrednictwem organu, którego działanie jest przedmiotem skargi. To z kolei powoduje, że w myśl art. 54 § 3 p.p.s.a. organ ten ma wówczas obowiązek rozważyć, czy skarga nie zasługuje na uwzględnienie w całości. W ten sposób ustawodawca zachował w tych sprawach prawo do remonstracji. Zmienił jednak jego postać z remonstracji samoistnej (czyli wezwania do usunięcia naruszenia prawa) na remonstrację niesamoistna, zawartą w skardze składanej do sądu administracyjnego. Warto podkreślić, że nie była to zmiana pozorna i nieznacząca.

W myśl art. $54 \S 3$ p.p.s.a. organ może uwzględnić skargę w całości. A zatem również $\mathrm{w}$ obecnym stanie prawnym, pomimo rezygnacji $\mathrm{z}$ wezwania do usunięcia naruszenia prawa, organ administracji publicznej po wniesieniu skargi może dokonać autorewizji własnego działania. Uwzględniając skargę w całości, winien stwierdzić, czy jego zaskarżone działanie nastapiło bez podstawy prawnej lub odbyło się z rażącym naruszeniem prawa. W każdym jednak z takich przypadków - w myśl zd. trzeciego art. 54 § 3 p.p.s.a. - organ, korzystając z uprawnienia do autoweryfikacji własnego działania, ma obowiązek wskazać, czy dokonało się ono z rażącym naruszeniem prawa. Można się spodziewać, że w obawie przed uniknięciem konsekwencji z tytułu popełnionego kardynalnego błędu oraz z chęci zachowania dobrego imienia i autorytetu organy administracji publicznej będą unikać stosowania tego przepisu.

Na marginesie rozważań warto nadmienić w kontekście rażącego naruszenia prawa, że analiza konstrukcji ponaglenia, wprowadzonego w wyniku ostatniej nowelizacji przepisów Kodeksu postępowania administracyjnego, prowadzi do wniosku, że ustawodawca, normując tę instytucję, zdawał sobie sprawę z iluzoryczności rozwiązania sprowadzającego się do „skarżenia

\footnotetext{
39 Zob. <https://www.mpit.gov.pl/strony/zadania/nowelizacja-kpa> [dostęp: 1.03.2019].

${ }^{40}$ Zob. <http://www.konsultacje.gov.pl/node/4204> [dostęp: 10.06.2017].

41 Kmieciak (2017): teza 2.
} 
na siebie samego". Z tego względu w sytuacji rozpatrywania ponaglenia przez ten sam organ, któremu strona zarzuca bezczynność lub przewlekłość,

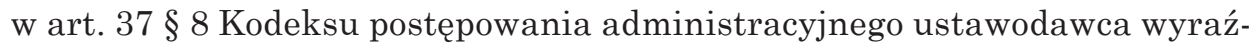
nie postanowił o wyłączeniu stosowania $\S 6$ nakazującego wskazywanie, czy (on sam) dopuszczając się bezczynności lub przewlekłości, uczynił to z rażącym naruszeniem prawa.

\section{OBIEKTYWIZM W ROZPATRYWANIU ŚRODKÓW PRAWNYCH}

Jak można przypuszczać, problem ten nie powstałby, gdyby dokonywanie autoweryfikacji powierzano innej osobie niż ta, która odpowiada za kwestionowany akt bądź działanie wcześniej poddane weryfikacji wezwaniem do usunięcia naruszenia prawa (a obecnie skarga). Nie miałaby ona bowiem tego typu dylematów, gdyż ewentualne błędy dostrzeżone przez nią w kwestionowanym akcie bądź czynności nie byłyby kojarzone z jej osoba. Nawiasem mówiąc, postawa osoby, do której trafia środek prawny, a która wcześniej odpowiadała za wydanie kwestionowanego aktu lub podjęcie kwestionowanej czynności albo ich brak, jest zjawiskiem naturalnym i ma swoje wyjaśnienie na gruncie psychologiczno-społecznym. W tym kontekście znaczenia nabiera precyzyjnie rozpoznane na gruncie nauk psychologicznych jedno z kluczowych zjawisk współczesnej psychologii społecznej o nazwie „dysonansu podecyzyjnego”, będącego przejawem dysonansu poznawczego ${ }^{42}$. Pojawia się ono każdorazowo po podjęciu jakiegoś rozstrzygnięcia przez jakąś osobę (grupę osób) i polega na podkreślaniu przez nią (przez nie) jego zalet oraz minimalizowaniu jego wad po to, aby zredukować dysonans, na który składają się wątpliwości i obawy pojawiające się po podjęciu rozstrzygnięcia. Przypomina to przekonywanie nie tylko samego siebie, ale i innych, że podjęta decyzja była najwłaściwsza z wszystkich możliwych. Dysonans podecyzyjny nieuchronnie pojawia się zarówno po podejmowaniu decyzji w zwykłych sprawach życia codziennego, jak i może on dotyczyć poważniejszej problematyki, w tym podejmowania decyzji w życiu zawodowym. Opisana na gruncie nauk psychologicznych powszechność występowania dysonansu podecyzyjnego pozwala przypuszczać, że może on dotyczyć podejmowania mniej czy bardziej sformalizowanych rozstrzygnięć prawnych. Prowadzi to do wniosku, że zjawisko dysonansu podecyzyjnego, pojawiające się po wydaniu aktu czy podjęciu czynności przez pracownika organu administracji publicznej, może mu uniemożliwiać „świeże” spojrzenie na sprawę z odpowiedniego dystansu. Jego sposób myślenia w tym momencie jest bowiem zdominowany przez naturalną skłonność (każdego człowieka znajdującego się w takiej sytuacji) do utrwalania słuszności powziętej wcześniej de-

${ }^{42}$ Twórca pojęcia dysonansu poznawczego w latach pięćdziesiątych ubiegłego stulecia był L. Festinger (2007). 
cyzji przez podkreślanie jej pozytywnych walorów i niedostrzeganie zarówno większych wad, jak i drobniejszych usterek $^{43}$.

Remedium na przezwyciężenie tych niedoskonałości mogłoby być rozwiązanie, w myśl którego zapoznanie się z wezwaniem do usunięcia naruszenia prawa i ewentualne udzielenie na nie odpowiedzi powierzano by każdorazowo innej osobie niż tej odpowiadającej za akt lub czynność, o których mowa w art. $3 \S 2$ p.p.s.a. i które były podstawą do wniesienia wezwania. Zaznaczyć jednak należy, że nie jest to możliwe w przypadku, gdy organ podejmujący rozstrzygnięcie działa w sposób plenarny, czego przykładem jest podejmowanie uchwał będących przepisami prawa miejscowego. W tych przypadkach więc zastapienie danego organu nie byłoby możliwe. To samo trzeba stwierdzić w odniesieniu do aktów, których podejmowanie ustawodawca przypisał do zakresu kompetencji kolegialnych organów wykonawczych powiatów oraz samorządów województw.

\section{OCENA WPROWADZONYCH ZMIAN}

Rezygnacja z wezwania do usunięcia naruszenia prawa wydaje się działaniem nieroztropnym. Nawet jeśli ustawodawca kierował się - jak można przypuszczać - niezbyt wysoką efektywnością tego środka prawnego, to jednak trzeba byłoby mieć na uwadze nie tylko to, że wprawdzie niezbyt często, ale jednak wezwania te okazywały się skuteczne, doprowadzając do zmiany stanowiska organu ${ }^{44}$, ale również (drugą stronę medalu) to, w jak wielu sprawach wzywajacy po zapoznaniu się z argumentacją organu odstapili od zamiaru wniesienia skargi do sądu administracyjnego ${ }^{45}$. Nie powinno się nie brać pod uwage tych przypadków, w których rezygnacja z wniesienia skargi była konsekwencją zapoznania się ze stanowiskiem organu wyrażonym w odpowiedzi na wezwanie.

Rezygnując z wezwania do usunięcia naruszenia prawa, ustawodawca najwyraźniej nie spostrzegł, że jego pozostawienie w dotychczasowym kształcie - samoistnej remonstracji - na którą organ może, ale nie musi odpowiedzieć, $\mathrm{z}$ uwagi na początkowy termin wniesienia skargi $\mathrm{w}$ rzeczywistości pozostawiałoby swobodę samemu administrowanemu w decydowaniu, czy faktycznie chce skorzystać z tego środka prawnego, czy traktuje go wyłącznie jako formalność, od której spełnienia zależało skuteczne wniesienie skargi. Uchwała NSA z 27 czerwca 2016 r. (I FPS 1/16) zakończyła spór co do kwestii początkowego terminu do wniesienia wezwania do usunięcia naruszenia prawa. Zgodnie z jej

43 Szewczyk (2018): 111-112, 126.

${ }_{44}$ Analiza dorobku doktryny pozwala na stwierdzenie, że wezwanie do usunięcia naruszenia prawa przyczyniało się do zmiany stanowiska w drodze autoweryfikacji. Było ono przydatne chociażby w przypadkach, kiedy podjęcie uchwały wymagało przeprowadzenia sformalizowanej procedury, tak jak np. w odniesieniu do planów miejscowych - zob. wyrok WSA w Krakowie z 17 października 2017 r., II SA/Kr 666/17, CBOSA.

45 Kmieciak (2017): 57-58. 
postanowieniami skargę można było wnieść „najwcześniej następnego dnia po dniu wniesienia wezwania do usunięcia naruszenia prawa, nie czekając na doręczenie odpowiedzi na to wezwanie”. Z uwagi na to, że skarżący nie był obowiązany czekać na doręczenie odpowiedzi przez organ administracji, on sam de facto decydował, czy liczy na pozytywny rezultat wniesionego wezwania, dając jednocześnie organowi administracji szansę naprawienia swoich błędów bez daleko idaccych konsekwencji (zob. zd. trzecie art. $54 \S 3$ p.p.s.a.).

Pochopna rezygnacja z wezwania do usunięcia naruszenia prawa jest tym bardziej niezrozumiała, gdy weźmie się pod uwagę cel ostatniej nowelizacji k.p.a. i p.p.s.a., którym była między innymi redukcja obciążeń sądów administracyjnych przez obniżenie liczby skarg, co z kolei ma prowadzić do oszczędności środków publicznych. Założeniem projektodawcy nowelizacji było poprawienie jakości działań administracji publicznej przez rozwiązanie trzech zasadniczych problemów: zbyt długi czas rozpoznawania spraw, nadmierny formalizm oraz rygorystycznie rozumiana władczośćc ${ }^{46}$. Wiele wprowadzonych na skutek tej nowelizacji rozwiązań miało na celu uproszczenie postępowania i zwiększenie jego skuteczności. Stanowiło to wyraźne nawiązanie do idei pragmatyzmu postępowania opartego na założeniu, że ma się ono toczyć szybko, sprawnie, oszczędnie, z ukierunkowaniem na osiagnięcie zaplanowanego efektu $^{47}$. Tymczasem, eliminując wezwanie do usunięcia naruszenia prawa z systemu środków prawnych, ustawodawca wbrew przyjętym założeniom odwrócił się od idei pragmatyzmu procesowego i wyeliminował w ten sposób mechanizm zapobiegajacy pochopnemu wnoszeniu skarg do sądów administracyjnych - kierując się ku antypragmatyzmowi. Usunął tym samym środek prawny, na którego istnieniu powinno mu specjalnie zależeć, gdyż wpisywał się on właśnie w założenia nowelizacji dążącej do zmniejszenia nadmiernego formalizmu. Wszak remonstracja, którą było wezwanie do usunięcia naruszenia prawa należy do grupy środków prawnych odformalizowanych ${ }^{48}$.

Tryb wstępnego, odformalizowanego postępowania - inicjowanego remonstracja - chronił (w pewnym stopniu) sądy przed zbędnymi skargami, nierokującymi szans powodzenia. A ponadto stanowił on instrument wzmacniający efektywność sądowej kontroli administracji ${ }^{49}$. W świetle powyższych uwag braku środka prawnego zapewniającego wstępną selekcję skarg wnoszonych do sądu administracyjnego nie można ocenić pozytywnie.

\section{Ewa Szewczyk}

Uniwersytet Zielonogórski

Wydziat Zamiejscowy w Sulechowie

e.szewczyk@wzs.uz.zgora.pl

https://orcid.org/0000-0002-2980-6564

\footnotetext{
${ }^{46}$ Gronkiewicz (2017): 23.

${ }^{47}$ Wegner-Kowalska (2017): $969 \mathrm{n}$.

48 Szewczyk (2018): XXXVI n.

${ }^{49}$ Kmieciak (2017): 58.
} 
Adamiak, B. (2017). Przesłanki dopuszczalności skargi do sądu administracyjnego, [w:] B. Adamiak, J. Borkowski, Postępowanie administracyjne i sądowoadministracyjne. Warszawa: $530-537$.

Chlebny, J. (2010). Standardy Rady Europy i Europejskiego Trybunału Praw Człowieka w procedurze administracyjnej i sądowoadministracyjnej, [w:] Z. Kmieciak (red.), Postępowanie administracyjne w Europie. Warszawa: 19-46.

Chróścielewski W. (2003). Wszczęcie postępowania sądowoadministracyjnego, [w:] Prawo o postępowaniu przed sądami administracyjnymi (zagadnienia wybrane). Materiał na konferencję sędziów NSA, Popowo 20-22 października 2003 r.). Materiały przeznaczone do użytku służbowego. Warszawa: 21-34.

Chróścielewski, W., Kmieciak, J., Tarno, J.P. (2004). Reforma sądownictwa administracyjnego - oczekiwania i zagrożenia, [w:] Procedura administracyjna wobec wyzwań współczesności, Łódź: $63-71$.

Festinger, L. (2007). Teoria dysonansu poznawczego. Warszawa.

Fundowicz, S. (2003). Zasada skargowości w polskim postępowaniu sądowoadministracyjnym, [w:] J. Stelmasiak et al. (red.), Polski model sądownictwa administracyjnego. Lublin: 127142 .

Glaezer, S. (1992). Das Vorverfahren in Form des Widerspruchsverfahrens, [w:] Verwaltungsprozessrecht. Kurzlehrbuch. 11. Auflage. Stuttgart-München-Hannover-Berlin: 109-138.

Gronkiewicz, A. (2017). Nowelizacja kodeksu postępowania administracyjnego - uwagi wprowadzające, [w:] Nowe instytucje procesowe w postępowaniu administracyjnym w świetle nowelizacji Kodeksu postępowania administracyjnego z dnia 7 kwietnia 2017. Katowice: 17-30.

Kisielewicz, A. (2009). Akty i czynności, o których mowa w art. 3 § pkt 4 ustawy z 30 sierpnia 2002 r. - Prawo o postępowaniu przed sądami administracyjnymi, [w:] Instytucje procesu administracyjnego i sądowo administracyjnego. Księga Jubileuszowa dedykowana Profesorowi Ludwikowi Żukowskiemu. Przemyśl-Rzeszów: 167-196.

Kmieciak, Z. (2009). Instancyjność postępowania administracyjnego (uwagi prawnoporównawcze), [w:] M. Wierzbowski et al. (red.), Księga jubileuszowa dedykowana Prof. zw. dr. hab. Jackowi M. Langowi. Warszawa: 137-144.

Kmieciak, Z. (2010a). Koncepcja zintegrowanego systemu odwoławczego w sprawach administracyjnych. Państwo i Prawo 66(1): 25-38.

Kmieciak, Z. (2010b). Prawo do sądu w sprawach sporów jednostki z administracją w świetle postanowień konwencyjnych, konstytucyjnych oraz europejskiego soft-law, [w:] Postępowanie administracyjne i sądowoadministracyjne a prawo europejskie. Warszawa: 95-169.

Kmieciak, Z. (2013). Wezwanie do usunięcia naruszenia prawa w postępowaniu administracyjnym i sądowoadministracyjnym. Zeszyty Naukowe Sądownictwa Administracyjnego 4: 25-38.

Kmieciak, Z. (2015). Wszczęcie postępowania przed wojewódzkim sądem administracyjnym [w:] Z. Kmieciak (red.), Polskie sądownictwo administracyjne - zarys systemu. Warszawa: 132-164.

Kmieciak, Z. (2017). Glosa do uchwały NSA z 27 czerwca 2016 r. I FPS 1/16, OSP 3. Lex online.

Łaszczyca G., Martysz C., Matan, A. (2005). Inne akty lub czynności z zakresu administracji publicznej jako przedmiot skargi do sądu administracyjnego (art. $3 \S 2$ pkt 4 p.p.s.a.), [w:] Podmioty administracji publicznej i prawne formy ich działania. Studia i materiały z konferencji jubileuszowej Profesora Eugeniusza Ochendowskiego. Toruń: 363-376.

Piątek, W. (2013). Wezwanie do usunięcia naruszenia prawa w postępowaniu sądowoadministracyjnym. Przegląd Sądowy 9: 43-61.

Piątek, W. (2017). Przebieg postępowania sądowoadministracyjnego, [w:] R. Hauser, A. Skoczylas (red.), Postępowania administracyjne i sądowoadministracyjne z kazusami. Warszawa: $420-464$.

Schmidt, R. (2011). Das Widerspruchsverfahren, [w:] Verwaltungsprozessrecht. 14. Auflage: $365-383$.

Stroink, F., Linden, E. van der (2005). Judicial Lawmaking and Administrative Law. Antwerpen-Oxford.

Szewczyk, E. (2011). Wezwanie do usunięcia naruszenia prawa. Zagadnienia wybrane, [w:] J. Niczyporuk (red.), Teoria instytucji prawa administracyjnego. Paryż: 637-648. 
Szewczyk, E. (2017). Remonstracja - zapomniany środek prawny, [w:] B. Jaworska-Dębska et al. (red.), O prawie administracyjnym i administracji. Refleksje. Księga Jubileuszowa dedykowana Profesor Małgorzacie Stahl. Łódź: 567-578.

Szewczyk, E. (2018). Remonstracja w prawie administracyjnym procesowym. Warszawa.

Tarno, J.P. (2016). Postępowanie przed sądem I instancji, [w:] W. Chróścielewski, J.P. Tarno, Postępowanie administracyjne i postępowanie przed sądami administracyjnymi. Warszawa: 433-456.

Wegner-Kowalska, J. (2017). Idea pragmatyzmu w postępowaniu administracyjnym, [w:] J. Zimmermann (red.), Aksjologia prawa administracyjnego. Warszawa: 965-976.

Wiktorowska, A. (2007). Skarga do sądu administracyjnego, [w:] M. Wierzbowski (red.), M. Szubiakowski, A. Wiktorowska, Postępowanie administracyjne - ogólne, podatkowe i przed sądami administracyjnymi. Warszawa: 409-413.

\section{A REQUEST TO REMOVE AN INFRINGEMENT - AN UNNECESSARY ELEMENT IN THE PROVISIONS OF THE COURT-ADMINISTRATIVE PROCEDURE?}

\section{Sum mary}

The Polish model of judicial control of the administration assumes that it is the element crowning the system of verification of administrative activities. Therefore, the mere launch of courtadministrative proceedings requires the exhaustion of appeals or, until recently, a call to remove the infringement. As a result of the reform of the administrative courts in mid-2017, this legal measure was eliminated from the provisions of the Act on Proceedings before Administrative Courts (APAC). The author answers the question of the extent to which the procedure of eliminating the summons to remove the violation of law from the provisions of the APAC - which had hitherto conditioned the effectiveness of lodging a complaint to the administrative court - was justified, and whether breaking with the fixed way of challenging acts and actions referred to in Article 3 para. 2 item 4 and 4 a may be assessed positively. On this occasion, she indicates that despite the exclusion of this legal measure from the provisions of the APAC, it still functions in Polish legislation.

Keywords: request to remove an infringement; judicial administration control 